\title{
Bovine Respiratory Syncytial Virus (BRSV): A review
}

\author{
By L. E. Larsen
}

Danish Veterinary Laboratory, Copenhagen, Denmark

\begin{abstract}
Larsen LE: Bovine respiratory syncytial virus (BRSV): A review. Acta vet. scand. $2000,41,1-24$. - Bovine respiratory syncytial virus (BRSV) infection is the major cause of respiratory disease in calves during the first year of life. The study of the virus has been difficult because of its lability and very poor growth in cell culture. However, during the last decade, the introduction of new immunological and biotechnological techniques has facilitated a more extensive study of BRSV as illustrated by the increasing number of papers published. Despite this growing focus, many aspects of the pathogenesis, epidemiology, immunology etc. remain obscure. The course and outcome of the infection is very complex and unpredictable which makes the diagnosis and subsequent therapy very difficult. BRSV is closely related to human respiratory syncytial virus (HRSV) which is an important cause of respiratory disease in young children. In contrast to BRSV, the recent knowledge of HRSV is regularly extensively reviewed in several books and journals. The present paper contains an updated review on BRSV covering most aspects of the structure, molecular biology, pathogenesis, pathology, clinical features, epidemiology, diagnosis and immunology based on approximately 140 references from international research journals.
\end{abstract}

enzootic pneumonia; pathogenesis; epidemiology; calves; disease.

\section{Introduction}

Coinciding with the intensification of the agricultural industry the frequency and severity of bovine respiratory diseases have increased and the disease is currently regarded as the principal health problem in calf rearing world-wide ( $\mathrm{Le}$ keux 1995). In Denmark, the incidence rate of respiratory disease has been estimated to be as high as 0.25 per day at risk in calves between 2 and 24 weeks of age (Uttenthal et al. 1996, Larsen et al. 1998). This economically important multifactorial health problem is characterised by several different terms including "enzootic pneumonia" (Uttenthal et al. 1996). The severity of disease seems to be influenced by the animal itself (immune status and general condition), the environment (housing conditions and climate), the management (number of animals per square meter, commingling of animals from multiple sources, stress factors, prophylactic precautions and management practices) and the presence and spreading of infectious agents such as virus and bacteria (Lekeux 1995). Numerous surveys in Denmark (Bitsch et al. 1976, Uttenthal et al. 1996) and elsewhere (Verhoeff \& Van Nieuwstadt 1984, Bryson et al. 1978) scrutinised the role of different specific pathogens in respiratory distress. Several species of bacteria and virus were found to be involved. Nevertheless, these studies unambiguously showed that bovine respiratory syncytial virus (BRSV) was the agent most often associated with severe epizootics of respiratory disease in especially younger dairy and beef calves. During the last decade increasing numbers of papers regarding infection with BRSV have been published, but many aspects of the pathogene- 
sis, epidemiology, immunology etc. remain obscure and the outcome of the infection under different circumstances seems to be very complex and unpredictable. BRSV is closely related to human respiratory syncytial virus (HRSV) (Lerch et al. 1989), which is an important cause of respiratory disease in children. The current knowledge of HRSV is regularly extensively reviewed in several books and journals, whereas there seems to be a need for an updated review covering most aspects of the BRSV and the infection induced by this virus. This review represents an attempt to compile the present knowledge of BRSV.

\section{History, taxonomy and host range}

During the autumn of 1955 an episode of respiratory illness was recognised in a colony of laboratory chimpanzees and in one laboratory employee in Washington D.C., USA (Morris et al. 1956). An apparently new virus, initially named "Chimpanzee Coryza Agent", was isolated from one of the diseased chimpanzees. The virus was later renamed: "Respiratory Syncytial Virus" in recognition of its characteristic cytopathological effect in cell culture (Chanock et al. 1957). A series of surveys in the early 1960 's established the importance of HRSV in respiratory disease of children worldwide (Chanock et al. 1961). More than 10 years later, a virus closely related to HRSV was isolated from calves during an epizootic of severe respiratory disease in Switzerland. The virus was named BRSV (Paccaud \& Jacquire 1970). Several surveys in the early 1980 's and onwards confirmed that BRSV is endemic in the calf population throughout the world (Baker et al. 1986a, Stott et al. 1980, Thomas et al. 1980, Uttenthal et al. 1996).

BRSV is a member of the pneumovirus genus within the Pneumovirinae subfamily of the Paramyxoviridae family that belongs to the virus order, Mononegavirales (Murphy et al. 1995).
The Pneumovirinae subfamily differs from the other paramyxoviruses by lacking neuraminidase - but having the fusiogenic activity. RSV also lacks haemagglutination activity possessed by most virus of the paramyxovirus genus and the pneumovirus, pneumonia virus of mice (PVM) (Richman et al. 1971). All members of the subfamily cause respiratory disease. In addition to the bovine and human respiratory syncytial viruses, antigenically related respiratory syncytial viruses are present in sheep (ORSV) and goats (CRSV) (Mallipeddi \& Samal 1993, Smith et al. 1979). HRSV, BRSV, ORSV and CRSV are structurally and antigenically very similar with the ruminant viruses being closest related (Mallipeddi \& Samal 1993, Trudel et al. 1989). In contrast to the human, bovine and ovine RSV no sequence data are available on the caprine virus. Thus, the presence of a separate caprine virus has been determined on basis of the level of cross-reactivity with BRSV specific antibodies in serum neutralisation test, only (Smith et al. 1979).

BRSV can replicate in a wide range of primary bovine cell cultures derived from the testis, turbinate, trachea, aorta, spleen and lung (Inaba et al. 1970, Jacops \& Edington 1971, Openshaw 1995, Bastien et al. 1997) and may also be adapted to grow in cell types from sheep ( $A l$ Darraji et al. 1982). BRSV was adapted to grow in different human cells in some studies (Matumoto et al. 1974), but not in others (Paccaud \& Jacquire 1970). HRSV may induce mild respiratory disease with few macroscopic lesions in calves under experimental conditions (Jacobs \& Edington 1975, Thomas et al. 1984), but there is no proof that BRSV can infect humans. Attempts to infect mice and guinea pigs failed (Matumoto et al. 1974), whereas sheep were successfully infected with BRSV (Trigo et al. 1984). RSV specific antibodies have been detected in sera from roes, cats and swine, but the virus has never been isolated from these 


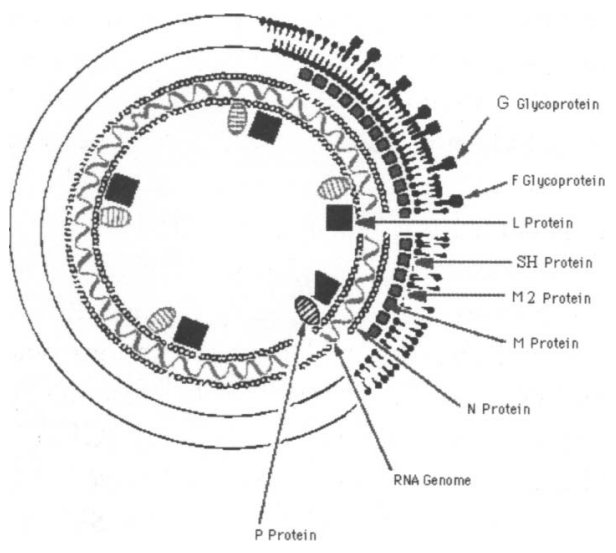

Figure 1. The structure of RSV. The names, sizes, properties and functions of the BRSV proteins are shown in the table (in the order 3 ' - to '5). ' Length in number of amino acids deduced from gene sequence; bEstimated mass $(\mathrm{kDa})$ of un-processed protein predicted from the amino acid sequence. See text for references.

\begin{tabular}{|c|c|c|}
\hline Protein & $\begin{array}{l}\text { Lenght }{ }^{a} / \\
\text { weight }^{b}\end{array}$ & Localization / Function \\
\hline NSI (Non-structural protein) & $136 / 15.2$ & Nonstructural, gene regulation \\
\hline NS2 (Non-structural protein) & $124 / 14.6$ & Nonstructural, unknown function (gene regulation?) \\
\hline $\mathrm{N}$ (Nucleocapsid protein) & $391 / 42.6$ & Nucleocapsid, virus transcription/replication \\
\hline P (Phosphoprotein) & $241 / 27.2$ & Nucleocapsid, virus replication/transcription \\
\hline M (Matrix protein) & $256 / 28.7$ & Membrane protein (inner surface), unknown function \\
\hline SH (Small hydrophobic protein) & $73 / 8.4$ & Transmembrane (surface exposed), fusion of cells \\
\hline G (Glycoprotein) & $\begin{array}{l}257 / 28.6 \\
\text { or } 263 / 29.0\end{array}$ & $\begin{array}{l}\text { Transmembrane (surface exposed), attachment to host } \\
\text { cells }\end{array}$ \\
\hline F (Fusion protein) & $574 / 63.8$ & Transmembrane (surface exposed), fusion of cells \\
\hline M2 (Matrix protein 2) & $\begin{array}{l}186 / 22(\text { ORF } 1) \\
95 / 11(\text { ORF } 2)\end{array}$ & $\begin{array}{l}\text { Membrane protein (inner surface with the M protein), } \\
\text { transcriptional elongation factor (ORF1) }\end{array}$ \\
\hline L (Polymerase protein) & $2161 / 200$ & Nucleocapsid, viral polymerase \\
\hline
\end{tabular}

species (Van der Poel et al. 1995, Allan et al. 1998).

\section{Structure and molecular biology}

Morphologically, BRSV appears as highly filamentous or pleomorphic virions with an average diameter of $200 \mathrm{~nm}$. A 7-15 nm thick lipid membrane derived from the host cell and covered with cub-shape projections of 7-19 nm in length, encloses the particles. The caprine and bovine virus particles form well-defined bridges linking them in a distinctive and unique network. Interestingly, HRSV apparently lacks these bridges (Al Darraji et al. 1982, Belanger et al. 1988, Trudel et al. 1989). The virus particle encloses the nucleoprotein-core tightly connected to the single-stranded RNA (Ito et al. 1973).

BRSV is sensitive to low $\mathrm{pH}$ and heating at $56^{\circ} \mathrm{C}$ for $30 \mathrm{~min}$. Exposure to diethyl ether, chloroform and other lipid solvents destroys infectivity (Paccaud \& Jacquire 1970, Smith et 


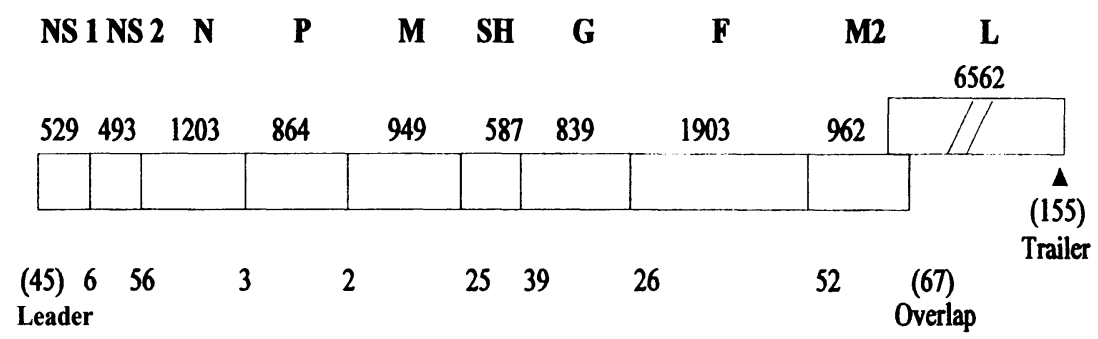

Figure 2. The gene order of the negative single stranded BRSV genome. The bold-face types are the abbreviations of the 10 coding proteins. The numbers shown above the genome states the number of nucleotides of each gene of BRSV, including the poly (A) template. The figures below indicate the size (nucleotides) of the leader and trailer region and of the intergenic junctions. The figures are those determined for the BRSV strain A51908. See text for references.

al. 1975). The virus is extremely fragile, but remains stable below $-50^{\circ} \mathrm{C}$ for many months. However, repeated freeze-thawing destroys infectivity. BRSV has a density of $1.23 \mathrm{~g} / \mathrm{ml}$ as determined by sucrose density gradient centrifugation (Ito et al. 1973).

The virus attaches to cells through the glycoprotein $\mathrm{G}$, but a specific receptor has not yet been identified (Levine et al. 1987). Immunofluorescence studies revealed that the virus specific proteins are located in the cytoplasm only (Berthiaume et al. 1974) and that the virus proteins assemble and mature on the apical surfaces of polarised epithelial cells (Roberts et al. 1995).

The negative strand RNA of RSV is neither capped nor polyadenylated and consists of approximately 15,222 nucleotides of which more than $85 \%$ code for protein (Huang \& Wertz 1982). The nucleotide sequences of all BRSV genes and intergenic regions have been published (Lerch et al. 1990, Lerch et al. 1991, Mallipeddi \& Samal 1992, Pastey \& Samal 1995, Samal \& Zamora 1991, Samal et al. 1991, Zamora \& Samal 1992, Zamora \& Samal 1992, Buchholz \& Conzelmann 1997, Buchholz et al. 1999). The order of transcription of these genes is shown in Fig. 2. All steps in the virus replicative cycles occur in the cytoplasm and probably follow the general schedule for negative strand viruses.

\section{Viral polypeptides and nucleic acids}

Ten viral polypeptides, with molecular weights very similar to those described for HRSV, are identified in BRSV infected cells (Fig. 1) (Cash et al. 1977, Lerch et al. 1989, Mallipeddi et al. 1990, Fisher et al. 1997).

\section{Attachment (G) glycoprotein}

The G glycoprotein of RSV mediates attachment of the virus to cells (Levine et al. 1987) and is unique among Paramyxoviridae since it lacks both neuraminidase and haemagglutinating activity (Richman et al. 1971). Furthermore, the amino acid sequence shows no similarity to any other known RNA virus protein described to date (Lerch et al. 1990). The G protein mRNA is for most BRSV strains calculated to 838 nucleotides in length excluding the poly (A) tail. The mRNA contains a single open reading frame (ORF) which encodes a polypeptide of 257 amino acids (Lerch et al. 1990, Larsen et al. 1998). Some BRSV strains possess a 6 amino acids extension at the C-terminal end (Furze et al. 1997, Mallipeddi \& Samal 1993). 


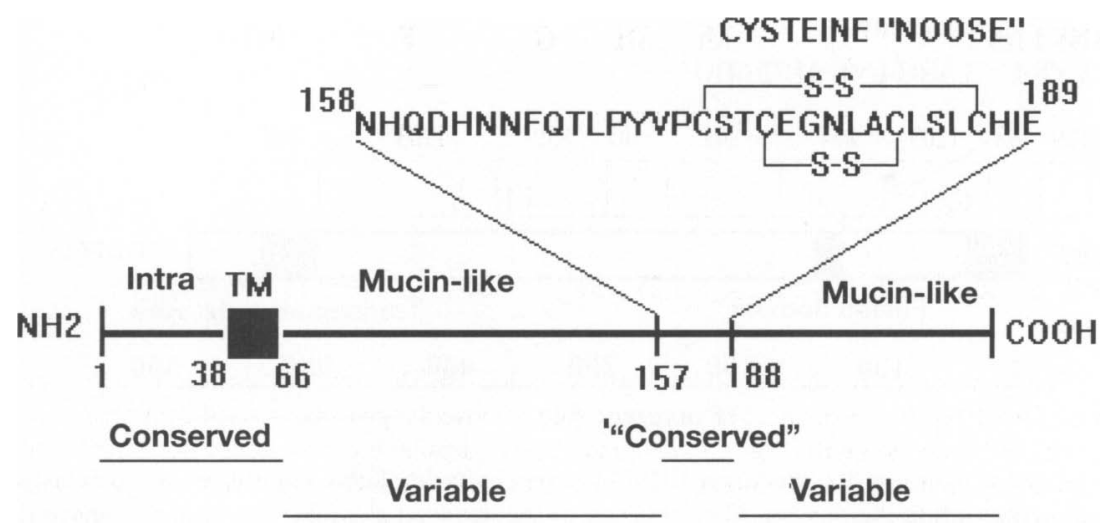

Figure 3. Structure of the RSV G protein. The "intra", "TM" and "mucin like" represent the parts of the protein which are situated intracellularly, transmembranelly and extracellularly, respectively. The amino acid sequence (one letter code) of the cysteine-noose of the reported BRSV strain (391-2) is also indicated. The figures below the structure indicate relatively conserved and variable parts of the protein, respectively. See text for references.

The amino acid sequence predicts a polypeptide with a mass of $28.6 \mathrm{kDa}$. However, a broad band migrating between 68 and $97 \mathrm{kDa}$ is revealed in SDS PAGE due to extensive glycosylation involving both $\mathrm{O}$ and $\mathrm{N}$ linked sidechains (Lerch et al. 1990). The G proteins of HRSV and BRSV are typical type II integral membrane proteins with a very atypically cysteine noose (Fig. 3). The G protein might exist as a multimer (dimer or trimer).

\section{Fusion (F) glycoprotein}

The fusion protein of BRSV is situated at the surface of virions (Himes \& Gershwin 1992) and is probably responsible for the fusion of the viral and host cell membranes and for the generation of syncytia between infected cells ( $\mathrm{Ma}$ theise et al. 1995). RSV fusion proteins are structurally and functionally related to the $\mathrm{F}$ proteins of other paramyxovirus (Richardson et al. 1986). The BRSV F mRNA comprises 1899 nucleotides excluding a poly (A) tail (Fig. 4). The gene contains a single open reading frame, which predicts a polypeptide of 574 amino ac- ids with an estimated molecular weight of 63.8 $\mathrm{kDa}$ (Lerch et al. 1991). The F protein is highly conserved among BRSV isolates $(97 \%$ to $99 \%$ homology) (Himes \& Gershwin 1992). The most variable site is the region preceding the cleavage site. The $\mathrm{F}$ protein is synthesized as a precursor $\left(\mathrm{F}_{0}\right)$, which consists of the $\mathrm{F}_{2}$ domain, the cleavage peptide and the $F_{1}$ domain (Lerch et al. 1991) (Fig. 4). The protein is post-translationally modified by mainly N-linked carbohydrate side-chains. The resulting $\mathrm{F}$ protein migrates as 3 bands at $68-\mathrm{kDa}$ (F0), $46 \mathrm{kDa}$ (F1) and 24-kDa (F2) in SDS-PAGE (Himes \& Gershwin 1992).

\section{Small hydrophobic protein (SH)}

The nucleotide sequences corresponding to the SH proteins of 2 different BRSV strains varies between 462 and 566 nucleotides in length. The mRNAs have major reading frames that predict polypeptides of 81 and 73 amino acids, respectively (Anderson et al. 1992, Samal \& Zamora 1991). The nucleotide sequence identity between these $2 \mathrm{BRSV}$ isolates was $85 \%$. The $\mathrm{SH}$ 


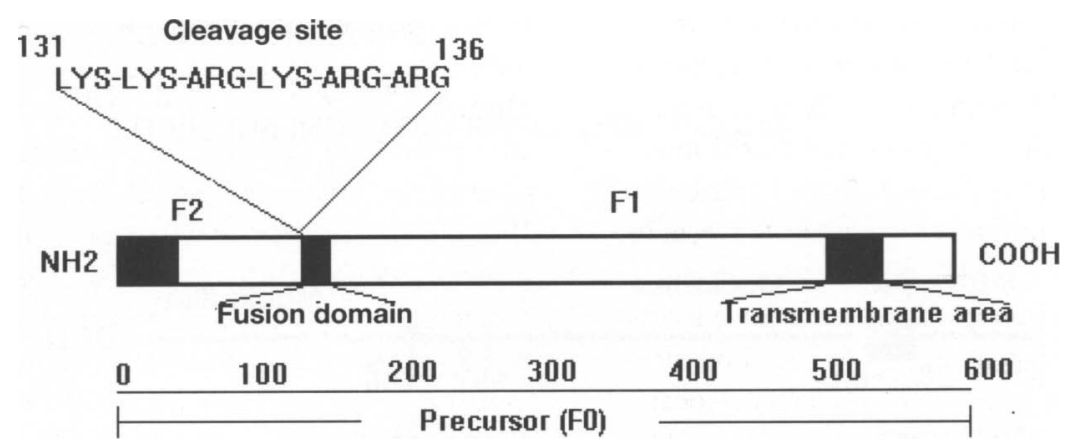

Figure 4. Linear structure of the precursor BRSV F protein. Hydrophobic regions are filled areas within the long rectangle representing the protein. The sequence of the deduced cleavage site is shown above the figure. The $\mathrm{F} 1$ and $\mathrm{F} 2$ subunits are generated by proteolysis of the cleavage site. This releases the hydrophobic domain at the $\mathrm{N}$ terminus of the $\mathrm{F} 1 \mathrm{unit}$, which is thought to be the fusion domain. See text for references.

protein is an integral membrane protein with the C-terminus at the extra-cellular side of the membrane (Collins \& Mottet 1993). Examinations of infected cells reveal several forms of the SH protein (Anderson et al. 1992, Olmsted $\&$ Collins 1989). The function of the SH protein is not fully defined, but the protein probably enhances the $\mathrm{F}$ protein mediated fusion of membranes and thereby contributes to the formation of syncytia (Pastey \& Samal 1997).

\section{Matrix protein (M)}

The nucleotide sequence corresponding to the BRSV M mRNA constitutes 938 nucleotides excluding the poly (A) tail. The deduced polypeptide is 256 amino acids long and has a calculated molecular weight of $28.7 \mathrm{kDa}$ (Samal \& Zamora 1991). This agrees closely with the apparent molecular weight of $29 \mathrm{kDa}$ determined in SDS-PAGE (Mallipeddi et al. 1990). The protein is moderately basic with a single hydrophobic region (residues 188 through 204). The function of the matrix protein is not clear, but its association with the membrane suggests that it may be involved in the interaction between the viral nucleocapsid and the cell membrane prior to assembly, maturation and budding of the virions. The $\mathrm{M}$ protein may also interact with the NS1 protein (Evans et al. 1996).

Nucleocapsid complex and associated proteins The inclusion bodies in the cytoplasm of RSV infected cells apparently lack membranes, contain amorphous material and are exclusively present in the cytoplasm in the vicinity of the cell nuclei.

The BRSV N protein mRNA is 1196 nucleotides long excluding the poly (A) tail (Samal et al. 1991). It encodes a polypeptide of 391 amino acids with a calculated molecular weight of $43 \mathrm{kDa}$ identical to that revealed in SDSPAGE (Mallipeddi et al. 1990). Sequence comparison of the nucleocapsid protein among several RNA viruses suggested a high degree of structural homology (Barr et al. 1991).

The $\mathrm{P}$ protein of BRSV is 860 nucleotides long, excluding the poly (A) tail (Mallipeddi \& $\mathrm{Sa}$ mal 1992). The sequence contains a single ORF of 723 nucleotides. The predicted protein is 241 amino acids long with a calculated molecular weight of $27 \mathrm{kDa}$. The high proportion of serine and threonine residues $(17 \%)$ reflects profound phosphorylation of the P protein of BRSV. Consequently, the $\mathrm{P}$ protein migrates as a discrete 
band of 34-38 $\mathrm{kDa}$ in SDS-PAGE (Mallipeddi et al. 1990). The 2 bovine isolates sequenced to date share $97 \%$ identity (Mallipeddi \& Samal 1992). The extent of post-translational modifications (phosphorylation) might contribute to the structural differences between different isolates (Shadomy et al. 1997).

The M2 protein does not seem to have a counterpart in other non-segmented negative strand viruses, but is associated with the nucleocapsid complex of the RS viruses (Garcia et al. 1993). The nucleotide sequence corresponding to the BRSV M2 mRNA is 958-962 nucleotides long, excluding the poly(A) tail (Zamora \& Samal 1992). The M2 gene contains 2 overlapping open reading frames (ORFs): The major ORF (ORF1) encodes a protein of 186 amino acids and is recognised in SDS-PAGE of extracts from cells infected with BRSV (Mallipeddi et al. 1990). The protein apparently lacks posttranslational modifications and consequently migrates corresponding to the predicted molecular weight of $22 \mathrm{kDa}$. The second ORF (ORF2), which overlaps the ORF1, potentially encodes a polypeptide of 95 amino acids ( $\mathrm{Col}$ lins et al. 1990). This ORF lacks a designated protein and it is unknown whether it is expressed in RSV infected cells. The protein product of ORF1 is involved in elongation of transcription whereas the putative ORF2 gene product might be associated with inhibition of RNA synthesis (Hardy \& Wertz 1998).

The BRSV L gene consists of 6562 nucleotides and contains a single open reading frame of 2161 amino acids. The protein shares $84 \%$ identity with the L protein of HRSV (Buchholz et al. 1999). Sequence comparison with the published sequences of other non-segmented negative strand viruses revealed the presence of 4 conserved motifs that are common for all RNA-dependent polymerases (Poch et al. 1990).

RS viruses are unique among paramyxoviruses in having 2 genes coding for non-structural (NS) proteins preceding the nucleoprotein. These NS proteins are among the most abundant proteins in RSV infected cells due to the polarity of transcription (Collins \& Wertz 1983). The NS1 (former 1C) gene of BRSV of a representative BRSV strain is 524 bases long, excluding the poly (A) tail. It encodes a protein of 136 amino acids with a predicted molecular weight of 15-kDa (Pastey \& Samal 1995). The NS2 (former 1B) gene of BRSV is 488 nucleotides long, excluding the poly (A) tail and encodes a protein of 124 amino acids. The protein has a calculated molecular weight of $14.5 \mathrm{kDa}$ consistent with that estimated from SDS-PAGE (Mallipeddi et al. 1990). Expression of the NS proteins in a baculovirus system generates multimer forms, probably as a consequence of intra- or inter molecular disulphide bindings involving the 4 and 2 cysteine residues present in the NS1 and NS2 proteins, respectively (Evans et al. 1996). The NS1 protein is a potent inhibitor of transcription and RNA replication (Atreya et al. 1998). The NS2 protein is not necessary for propagation of the virus in vitro (Buchholz et al. 1999).

\section{Pathogenesis and pathology \\ Experimental infections}

Numerous attempts to induce BRSV infection in conventional and colostrum-deprived calves have been published during the last 2 decades. A recent review described the experimental outlines and major results of 19 of these studies (Belknap et al. 1995). At least 3 novel important studies were, however, not included in this review (Otto et al. 1996, Taylor et al. 1995, Van der Poel et al. 1996). These experimental inoculations were generally unable to reproduce disease as severe as that seen during natural outbreaks. Furthermore, in the few studies capable of inducing fulminate disease, bacteriological examinations were not done or microbio- 
logical contamination was detected that may have influenced the clinical picture. The most successful of these experimental designs included more than one inoculation per day for up to 4 consecutive days which greatly hampered the interpretation of the data. However, recently it has been demonstrated that the clinical symptoms seen in the field repeatedly can be experimentally reproduced by a single BRSV inoculation, which thereby proves its primary etiological role (Larsen et al. 1999). Despite the former reservations, most of the experimental studies provided some useful data on the pathogenesis, pathology and immunology of BRSV infections, which are included in the following sections, when appropriate.

\section{Pathogenesis}

The pathogenesis of RSV infection is not clear, but accumulated data indicate that immune-mediated mechanisms play a dominating role. Another important aspect of the pathogenesis of respiratory disease caused by BRSV (and other respiratory viruses) is that the virus enhances bacterial colonisation and adherence and alters the specific and non-specific defence mechanism of the respiratory tract. Thus, it has been estimated that $90 \%$ of bacterial pneumonias in general develops after a previous viral infection (Babiuk et al. 1988).

\section{Macroscopic pathology}

The macroscopic changes observed in the respiratory tract of calves, following natural infection with BRSV, are characterised as typical interstitial pneumonia particularly involving the cranio-ventral part of the lungs (Bryson et al. 1983, Collins et al. 1988, Kimman et al. 1989, Pirie et al. 1981, Viuff et al. 1996). In this region, the consolidated lung areas encompass from a few lobuli to one half of the total lung area. The bronchi and bronchioles are often filled with mucopurulent exudate and haemor- rhage and emphysema may be present (Johnson et al. 1982). The interlobular septa often appear broad owing to pronounced oedema. The craniodorsal and dorsal portions of the lungs often appear normal, but may also be markedly distended due to oedema and severe alveolar, interstitial and subpleural emphysema. The emphysema appears to be caused by widespread bronchoobstruction and probably results in severe dyspnoea (Pirie et al. 1981). The mucosae of the nose, trachea and bronchi may be hyperaemic, especially at early stages of infection, probably reflecting ongoing viral replication (Bryson et al. 1983). The bronchial and mediastinal lymph nodes are often markedly enlarged, oedematous and occasionally emphysematous. In experimental studies, only few changes were seen on 2-5 days past infection (PID) whereas profound changes appeared on days 5-8. Some workers observed only minimal changes on day 10-14 (Bryson et al. 1983, Castleman et al. 1985a, Mohanty et al. 1975) in contrast to the moderate to severe changes encountered on days 14-16 by others (Thomas et al. 1984).

\section{Microscopic pathology}

Histologically, bronchitis and peribronchitis accompanied by a large number of syncytial cells in the nasal and tracheal mucosae and alveolar and bronchiolar epithelium are characteristic findings in calves after natural BRSV infection (Collins et al. 1988, Kimman et al. 1989, Thomas \& Stott 1981, Viuff et al. 1996). The viral antigen is first detected in the bronchiolar epithelium, later in the alveolar cells and may also be detected in the alveolar macrophages (Castleman et al. 1985b). There are conflicting reports on the role of alveolar macrophages in the BRSV pathogenesis, but it seems likely that at least a subset of these cells may be permissive for replicating BRSV and thereby contributes to the pathogenesis, i.e. by decreased functional ability. The activated macrophages may 
also release specific cytokines that might contribute to the pathologies (Midulla et al. 1993, Panuska et al. 1990, Schrijver et al. 1995, Sharma \& Woldehiwet 1996, Toth \& Hesse 1983). The virus is capable of cell-to-cell spread resulting in the generation of the characteristic syncytial giant-cells. However, the virus may also enter the lower airways by aspiration of virus containing respiratory secretions. A viraemic phase has not been reported and the virus is very seldom found outside the respiratory system (Van der Poel et al. 1996). Degeneration, necrosis and hyperplasia of bronchial epithelium and of lymphoid tissue around the bronchi are consistently present. The exudate frequently found in the lumen of bronchi and bronchiole contains mainly epithelial cells, neutrophils and occasionally eosinophils often accompanied by oedema and formation of hyaline membranes (Baker et al. 1986, Bryson et al. 1983, Kimman et al. 1989, Pirie et al. 1981). BRSV specific antigens and nuclei acids have been demonstrated in nasal and tracheal mucosae and epithelial cells of the bronchi and bronchiole and in alveolar type I and II cells (Haines et al. 1989, Lokensgard et al. 1992, Bryson et al. 1991, Viuff et al. 1996). The findings of hyaline membranes and eosinophils in the caudal lung areas, even in areas where no virus was detected, further indicate that immuno-mediated pathological effects may play an important role in the pathogenesis (Kimman et al. 1989).

\section{Clinical features and therapy}

Mild respiratory disease is characterised by coughing, mucous to seropurulent nasal discharge, slight to moderate increased respiratory rates and abnormal breathing sounds. Moderately affected calves exhibit respiratory rates above $80 / \mathrm{min}$, tachypnoea, harsh lung sounds across most of the lung wall and profound coughing. The most severely affected calves may be dyspnoeic and have subcutaneous, em- physematous bullae, although emphysema is not consistently found. Generalised symptoms range from slightly elevated rectal temperature, mild CNS depression and anorexia to high fever, deep depression and coma (Baker et al. 1986b, Bryson et al. 1978, Kimman et al. 1988). In experimental studies, the onset and duration of clinical disease varied considerably, but symptoms were generally present between day 2 and day 8 after infection (Belknap et al. 1995).

The therapy of BRSV infections is primarily of supportive character. Thus, concentrate and silage should be withdrawn from severely diseased animals and dehydration may be corrected by oral or intravenous administered fluids. Since immune-mediated mechanisms may contribute to the clinical symptoms, corticosteroids or non-steroid anti-inflammatory drugs (NSAIDs) may prove beneficial, but this has not been shown in controlled clinical trials. Antiviral therapy (ribavirin) has been approved for treatment of HRSV infections in children in form of aerosols, but this form of therapy is cumbersome and very expensive which would limit its use in veterinary practice (Collins et al. 1996). BRSV infections are often associated with secondary bacterial pneumonia (Babiuk et al. 1988, Larsen et al. 1999). Therefore, when respiratory disease is first recognised, treatment of all susceptible calves with anti-microbiological agents is often initiated. The use of antibiotics may decrease the incidence of severe respiratory complications, but results in significant economical loss for the farmer and is of growing public concern due to the risk of inducing drug-resistant bacteria.

\section{Diagnosis}

In conventional diagnostic work the demonstration of BRSV is often performed only on lung tissues that are available from post mortem samples only. Alternatively, samples for vi- 
rus/antigen detection may be obtained by the use of lung lavage, tracheal washes and/or nasal swabs, which can be collected from living calves. It should be emphasized, however, that nasal swabs collect virus present in the upper airways only. Thus, during later stages of active BRSV infections large amounts of BRSV may be present in the lungs even if no virus is present in the nasal cavity (Pirie et al. 1981, Larsen et al. 1999). The most diseased calves may not be the best candidates for sampling since the amount of virus seems to reach maximum levels 2 to 3 days before the onset of severe clinical symptoms as revealed in several experimental infections (Belknap et al. 1995). Most appropriate, samples should be collected from calves exhibiting mild respiratory symptoms such as mild coughing and/or slightly elevated temperature or from pen-mates to severely diseased calves.

The classical method of diagnosing BRSV infection is to isolate the virus in cell culture. This method is, however, time consuming and ineffective when not performed immediately after collection of the sample. The immunofluorescent antibody test (IF) has been the most common used alternative test in the veterinary diagnostic laboratory (Thomas \& Stott 1981). However, numerous different enzyme-linked immunosorbent assays (ELISAs) have been developed for the detection of BRSV (Lokensgard et al. 1992). The reliability and accuracy of these antigen detection tests are dependent of the reagents used and particularly of the sensitivity and specificity of the anti-BRSV antibody applied. In general, the antigen detection tests are fast, reliable and easy to perform. Application of more sensitive nucleic acid detection tests such as polymerase chain reaction (PCR) and probe hybridisation also does not require infectious virus and they are not affected by the presence of antibodies (Belak \& Ballagi Pordany 1993, Larsen et al. 1999). However, these tests are often cumbersome, time consuming and expensive to perform.

The diagnosis of BRSV infection may also be performed indirectly, i.e. by measuring specific antibodies against the virus in acute or convalescent serum. A variety of different assays have been used for detection of BRSV specific antibodies (Paccaud \& Jacquire 1970, Potgieter \& Aldridge 1977, Martin 1983, Westenbrink et al. 1985). Among them, a variety of ELISAs which specifically detect antibodies directed against BRSV specific proteins (Westenbrink et al. 1985, Samal et al. 1993, Langedijk et al. 1996) and the different immunoglobulin isotypes (Kimman et al. 1987, Westenbrink \& Kimman 1987). As with all serological tests used to determine the cause of an outbreak of infectious disease, paired serum samples taken 2 to 3 weeks apart are recommended. Because of the presence of maternal antibodies, these classical sero-diagnostic methods are often useless in the diagnosis of BRSV infections in calves less than 3 months of age, but have proved useful in the diagnosis of BRSV infections in older calves (Kimman et al. 1988, Uttenthal et al. 1996, Westenbrink \& Kimman 1987). The major disadvantage of paired serum samples is, however, the long time period from the start of the outbreak to a final diagnosis is provided. The use of isotype-specific ELISAs provides a suitable diagnostic alternative. Maternally transferred antibodies are restricted to the IgG1 isotype in calves (Kimman et al. 1987 ). Consequently, the presence of other isotypes in the serum of calves may therefore be indicative of an active BRSV infection (Kimman \& Westenbrink 1990, Kimman et al. 1987, Kimman et al. 1988, Westenbrink \& Kimman 1987).

In summary, it is obvious that the diagnosis of BRSV infection on herd-basis should be based on samples from more than one acute diseased animal and that most predictive results are ob- 
tained if more than one test is performed on each animal. Finally, it is important to evaluate the outcome of the different diagnostic tests on basis of the disease history, age of the animals, previous treatments etc. before a proper diagnostic answer can be reached.

\section{Epidemiology}

Infection has been induced in a variety of breeds, but certain breeds may be more susceptible than others (Baker et al. 1986b, Bryson et al. 1983, Thomas et al. 1984, Inaba et al. 1970, Bryson et al. 1983). During natural outbreaks of BRSV, clinical disease is seldom seen in calves less than 2 weeks of age, and disease is most severe in calves aged one to 5 months and is virtually absent in calves more than 9 months of age (Baker et al. 1986). Nevertheless, in certain areas adult cattle may experience severe disease following BRSV infection (Ellis et al. 1996, Elvander 1996).

The mode of transmission during the cause of natural infection has not been defined, but direct contact is probably required. Experimental data, however, suggest that aerosol transmission may also be possible over short distances (Mars et al. 1999, Smith et al. 1975). The high prevalence of antibodies against BRSV suggests that the infection is endemic in most areas (Baker et al. 1986, Uttenthal et al. 1996). In these regions, outbreaks of clinical disease often occur sporadically involving only the most susceptible groups of calves, while outbreaks involving thousands of cattle of all ages were reported in the early seventies (Inaba et al. $1972)$. With a morbidity of this level $(80 \%$ $100 \%$ ), the mortality rate seldom exceeds $5 \%$ $10 \%$, although it occasionally may be higher (Bryson et al. 1978, Inaba et al. 1972). To give a precise estimate of the true incidence rate of BRSV is difficult, since other pathogens such as parainfluenza-3 virus, bovine virus diarrhoea virus, bovine corona virus, bovine herpes 1 vi- rus and several bacterial agents may be involved. On the other hand, outbreaks of respiratory disease due to secondary bacterial infections may have been triggered by a previously subclinical BRSV infection (Larsen et al. 1999).

In temperate climates most outbreaks caused by BRSV occur in the early winter season (Van der Poel et al. 1993). In closed dairy farms, annual reinfections, recognised as clinical respiratory disease, often strike the replacement calves (Verhoeff \& Van Nieuwstadt 1984).

It is not known how BRSV survives between outbreaks. The virus might circulate at a very low level among seropositive cows from which it can periodically be reactivated (Van der poel et al. 1995). The reappearance of virus in closed herds might also be explained by persistence since attempts to reactivate BRSV by corticosteroid treatment of previously infected calves caused a fourfold increase in BRSV specific antibody titers (Van der Poel et al. 1997). Changes in the climate may augment BRSV infections, i.e. sudden change in outdoor temperature, particularly to wet and windy weather, often coincides with the onset of respiratory disease (Baker et al. 1986b). Factors affecting mucocilliary action (i.e. high levels of ammonia, high relative humidity, extreme temperature variations) are considered particularly important (Baker et al. 1986a, Bryson et al. 1978). Several surveys clearly showed that separate housing of calves significantly decreases the incidence of severe respiratory disease (Kimman et al. 1988, Stott et al. 1980). Nevertheless, even herds with excellent housing conditions and management may experience severe outbreaks, suggesting that BRSV can induce disease without environmentally predisposing factors (Baker et al. 1986a).

\section{BRSV subgroups}

BRSV isolates have been characterised on the 
basis of monoclonal antibody (MAb) reaction patterns against panels of BRSV G-protein specific, monoclonal antibodies (Furze et al. 1994, Furze et al. 1997, Schrijver et al. 1996, Larsen et al. 1998) and by nucleotide sequencing of the G protein (Furze et al. 1997, Mallipeddi \& Samal 1993, Prozzi et al. 1997, Stine et al. 1997, Larsen et al. 1998). Based on antigenic reactivity BRSV isolates were divided into 3 subgroups (designated A, B and intermediate or AB) exhibiting considerable differences in reactivity with MAb, but with limited sequence variability (up to $15 \%$ ). Mapping studies showed that the G specific MAb used for subgrouping each binds to the region between amino acids 174 and 210, which includes the cysteine noose (Fig. 3) (Furze et al. 1997, Langedijk et al. 1997). Thus, single amino acid changes at certain positions in the cysteine noose have major structural and functional consequences and thereby determine the subgroup distinction. The biological significance of the appearance of different subgroups of BRSV has not yet been assessed, but some degree of cross protection is evident.

\section{Humoral immunity}

Despite decades of research on the immunity and the immunopathological mechanism involved in the pathogenesis of RSV infections, several intriguing questions remain to be solved. The age of the animal, animal species, immune status and quality and quantity of serum and local antibodies are believed to influence the level of protection. Nevertheless, so far it has not been possible to prove a clear link between protection and level of actively produced or passively acquired antibodies in natural BRSV infection.

\section{Serum antibodies}

Experiments on the kinetics of the antibody responses to BRSV have generated conflicting re- sults, probably due to different sensitivity of the applied tests. Thus, 2 authors (Castleman et al. 1985b, Elazhary et al. 1984) detected (low level) of antibodies as early as 3 days after inoculation. In several other reports, antibodies were not detected before 7-10 days after inoculation (Jacobs \& Edington 1975, Kimman et al. 1987). In all studies, the neutralising antibodies persisted in serum for months. Antibodies of the IgM class have been detected in sera from gnotobiotic calves on days 8-10 after experimental BRSV infection, peaked on days 10-13 and remained detectable for 7-29 days (Kimman et al. 1987, Thomas et al. 1984, Westenbrink et al. 1985). $\mathrm{IgG}_{1}$ was detectable from days $13-17$, peaked on days $24-38$ and remained detectable for up to 8 months after experimental infections (Kimman et al. 1988, Schrijver et al. 1996). The half-life of acquired BRSV-specific IgG has been calculated to 2132 days. Expectedly, the $\mathrm{IgG}_{2}$ isotype did not appear in serum until days 25-86; peaked on days 38-90 and lasted for at least 8 months. Serum IgA may be detected concurrently with the IgM (Kimman et al. 1987) or be absent (Thomas et al. 1984).

\section{Local immune response}

The protective role of mucosal antibodies in the clearance of the virus during BRSV infection is not fully defined, although it has been the subject of several experiments (Kimman \& Westenbrink 1990, Kimman et al. 1987, Kimman et al. 1989a, Kimman et al. 1987, Westenbrink et al. 1989). IgM and IgA were the only classes of antibodies found in secretions from the eye, nose and lungs of colostrum deprived calves 810 days after experimental infection (Kimman et al. 1987). IgA remained detectable for up to 3 months or longer, while local IgM persisted for 10 to 18 days, only. Local IgG was not detected in this study, while BRSV specific mucosal IgG antibodies were detected up to 42 days 
after (3) vaccinations with modified-live or glutaraldehyde inactivated vaccine (Stott et al. 1984). In addition, IgG appeared on days 7-12 in nasal secretions from experimentally infected lambs (Sharma \& Woldehiwet 1996). Virus administered intramuscularly to seronegative calves or infection of calves with maternal antibodies failed to induce a primary mucosal response, but did prime for a local memory response as revealed by a strong, rapid and probably protective response at rechallenge (Kimman et al. 1989a). Thus, it appears that protection is not clearly associated with the presence of $\operatorname{IgA}$ at the mucosae at the time of challenge but with the ability to mount a rapid and strong response. A peculiarity of the $\operatorname{IgA}$ mucosal response in BRSV infected animals is the apparently long duration and course (Kimman \& Westenbrink 1990).

\section{Maternally acquired antibodies}

Remarkably, most cases of severe BRSV mediated disease develop in calves aged 1-3 months, at which time they still possess maternal antibodies in serum (Kimman et al. 1988, Stott et al. 1980). Nevertheless, maternal antibodies may be protective to a certain degree, since the severity and incidence of disease in calves less than 3 months of age seem to be inversely related to the serum level of (maternally derived) BRSV specific antibodies (Kimman et al. 1988, Stott et al. 1980).

\section{Cell mediated immunity}

Several studies revealed a profound cytotoxic (CD8+) T-cell response in the peripheral blood of calves (Thomas et al. 1996) and lambs (Sharma \& Woldehiwet 1996, Sharma et al. 1990) 5 to 10 days after experimental infection with BRSV. Furthermore, significant proliferative responses of CD4+ T-cells and increased IL-2 and INF $\gamma$ concentrations (the only cytokines measured) were observed in calves fol- lowing vaccination with modified live or inactivated vaccines (Ellis et al. 1992). Depletion of CD8+ T-cells in experimentally infected calves affected neither the serum nor local antibody responses to BRSV, whereas depletion of CD4+ cells suppressed the antibody response (Taylor et al. 1995, Thomas et al. 1996). Depletion of CD8+ cells, but not CD4+ cells, resulted in delayed viral clearance and increased the severity of lung consolidation. These studies provided evidences for the importance of a strong CD8+ $\mathrm{T}$-cell response in the clearance of virus in calves. Roles of (different subsets of) CD4+ Tcells and other subsets of T-cells (i.e. $\gamma \delta \mathrm{T}$-cells) are more uncertain and need further research.

\section{Immunopathology}

In the mid-sixties, a formalin-inactivated vaccine against HRSV was tested in children aged 4 months to 9 years. Forty-seven to $97 \%$ of the vaccinees developed significant increase in serum neutralising antibody titers (Fulginiti et al. 1969). Unexpectedly, much higher ratios of vaccinated children were infected with HRSV during the following winter season. Furthermore, the vaccine not only failed to confer protection, but also induced an exacerbated, altered clinical response. Post-mortem examinations of 2 vaccinated children, who died of pneumonia, revealed high levels of HRSV in the lungs and widespread bronchiolitis with peribronchial infiltration of monocytic cells, mainly eosinophils (Kim et al. 1969). Closer examinations of the serum from these children revealed that most of the antibodies directed against the $\mathrm{F}$ protein, lacked neutralising and fusion-inhibiting activities. This might have contributed to the potentiation of disease (Murphy et al. 1986, Murphy \& Walsh 1988). The mechanism behind the immunopathological effects of antibodies is not completely elucidated at present. Complement activation (Kimman et al. 1989b), type I and II hypersensitivity reactions (Kimpen 
et al. 1992), type III hypersensitivity reactions (Arthus reaction) (Kimman \& Westenbrink 1990), antibody-dependent enhancement ( $G i$ menez et al. 1996) and delayed virus clearance (Murphy et al. 1986) have been suggested as possible explanations. The dose, route of administration and employed adjuvant may also determine the response to administered antigens and vaccines (Vaux Peretz et al. 1992).

Resistance to viral infections (and most other intracellular microbes) is believed to be linked to the development of predominant Th1-like responses (Abbas et al. 1996). Interestingly, several studies have indicated that predominately $\mathrm{Th} 2$ cells are responsible for the immunopathological changes seen after RSV infection or vaccination (Jackson \& Scott 1996) and that the different RSV proteins activate different subsets of Th cells (Alwan \& Openshaw 1993, Gershwin et al. 1998, Jackson \& Scott 1996).

\section{Cytokines}

It is evident that the outcome of RSV infection is influenced by several factors of the adaptive and non-adaptive immune system. The key signals (or regulators) of the immune response are the cytokines. A variety of different cells (NK cells, T-cells, macrophages, epithelial cells, Bcells etc.) have the potentials of secreting specific cytokines in response to stimulation. The contribution or lack of contribution of some of these subsets of cells may thereby determine the outcome of disease (Graham 1996). Previous infection, vaccination, and maternal antibodies are examples of factors which may change the balance of the local cytokine response and thereby trigger either a protective response (Th1-like) or initiate the cascade that subsequently leads to exacerbated disease (Th2-like). In order to understand the immunological mechanisms involved on the pathogenesis of BRSV all these factors have to be considered.

\section{Immunoprophylaxis}

There is a great need for protective vaccines against HRSV and BRSV. Appropriate vaccines must be able to confer protection even in the presence of maternal antibodies, must protect against all subtypes and should lack disease exacerbating side effects.

Several inactivated and modified live BRSV vaccines are available, although proper assessment of protection is hampered by the lack of suitable experimental protocols (Belknap et al. 1995). The few published field trials, with live or attenuated vaccines, revealed different levels of protection (Taylor et al. 1989, Mohanty et al. 1981, Fulton et al. 1995, Gershwin et al. 1998, Howard et al. 1987, Kubota et al. 1992, Verhoeff \& van Nieuwstadt 1984) while other reports found that vaccination enhanced disease in calves (Gershwin et al. 1998, Kimman et al. 1989b). Intramuscular administration, especially in calves that possessed maternal antibodies, seems to be least effective in inducing protection whereas intranasal inoculation of live virus in colostrum deprived calves proved most effective (Gershwin et al. 1998, Kimman et al. 1989a). DNA based vaccines may prove to be useful in the future, but these are still in the early experimental phase (Schrijver et al. 1997).

\section{Acknowledgements}

The author is grateful for the scientific and typographically advices provided by Senior Scientist Aase Uttenthal, Danish Veterinary Institute for Virus Research and Professor Merete Blixenkrone-Møller, The Royal Veterinary- and Agricultural University, Denmark. The Danish Ministry of Food, Agriculture and Fisheries is thanked for financial support. 


\section{References}

Abbas AK, Murphy KM, Sher A: Functional diversity of helper T lymphocytes. Nature 1996, 383, 787793.

Al Darraji AM, Cutlip RC, Lehmkuhl HD, Graham $D L$, Kluge JP, Frank $G H$ : Experimental infection of lambs with bovine respiratory syncytial virus and Pasteurella haemolytica: clinical and microbiologic studies. Am.J.Vet.Res. 1982, 43, 236240.

Allan GM, McNeilly F, Walker IW, Young JA, Fee $S$, Douglas AJ, Adair BM: Serological evidence for pneumovirus infections in pigs. Vet. Rec. 1998, $142,8-12$.

Alwan WH, Openshaw PJ: Distinct patterns of T- and B-cell immunity to respiratory syncytial virus induced by individual viral proteins. Vaccine 1993, 11, 431-437.

Anderson $K$, King AM, Lerch RA, Wertz $G W$ : Polylactosaminoglycan modification of the respiratory syncytial virus small hydrophobic $(\mathrm{SH})$ protein: a conserved feature among human and bovine respiratory syncytial viruses. Virology 1992, 191, 417-430.

Atreya PL, Peeples ME, and Collins PL: The NS1 protein of human respiratory syncytial virus is a potent inhibitor of minigenome transcription and RNA replication. J.Virol. 1998; 72(2), 1452-61.

Babiuk LA, Lawman MJP, Ohmann HB: Viral-bacterial synergistic interaction in respiratory disease. Adv.Virus Res. 1988, 35, 219-242.

Baker JC, Ames TR, Markham RJF: Seroepizootiologic study of bovine respiratory syncytial virus in a dairy herd. Am.J.Vet.Res. 1986, 47, 240-245.

Baker JC, Ames TR, Werdin RE: Seroepizootiologic study of bovine respiratory syncytial virus in a beef herd. Am.J.Vet.Res. 1986a, 47, 246-253.

Baker JC, Werdin RE, Ames TR, Markham RJF, Larson $V L$ : Study on the etiologic role of bovine respiratory syncytial virus in pneumonia of dairy calves. JAVMA. 1986b, 189, 66-70.

Banerjee AK, Barik $S$, De BP: Gene expression of nonsegmented negative strand RNA viruses. Pharmac. Ther. 1991, 51, 47-70.

Barik $S$ : Transcription of human respiratory syncytial virus genome RNA in vitro: requirement of cellular factor(s). J.Virol. 1992, 66, 6813-6818.

Barr J, Chambers P, Pringle CR, Easton AJ: Sequence of the major nucleocapsid protein gene of pneumonia virus of mice: sequence comparisons suggest structural homology between nucleocapsid proteins of pneumoviruses, paramyxoviruses, rhabdoviruses and filoviruses. J.Gen.Virol. 1991, 72, 677-685.

Bastien N, Taylor G, Thomas LH, Wyld SG, Simard C, Trudel $M$ : Immunization with a peptide derived from the $\mathrm{G}$ glycoprotein of bovine syncytial virus (BRSV) reduces the incidence of BRSV- associated pneumonia in the natural host. Vaccine $1997,15,1385-1390$.

Belak S,Ballagi Pordany A: Application of the polymerase chain reaction (PCR) in veterinary diagnostic virology. Vet.Res.Commun. 1993, 17, 5572.

Belanger F, Berthiaume L, Alain R, Lussier G, Trudel $M$ : Electron microscopic evidence for bridges between bovine respiratory syncytial virus particles. J.Gen.Virol. 1988, 69, 1421-1424.

Belknap EB, Ciszewski DK, Baker JC: Experimental respiratory syncytial virus infection in calves and lambs. J.Vet.Diagn.Invest. 1995, 7, 285-298.

Berthiaume L, Joncas J, Pavilanis V: Comparative structure, morphogenesis and biological characteristics of the respiratory syncytial (RS) virus and the pneumonia virus of mice (PVM). Arch.Ges.Virusforsch. 1974, 45, 39-51.

Bitsch V, Friis NF, Krogh $H V$ : A microbiological study of pneumonic calf lungs. Acta.Vet.Scand. 1976, 17, 32-42.

Bryson DG, McConnell S, McAliskey M, McNulty $M S$ : Ultrastructural features of alveolar lesions in induced respiratory syncytial virus pneumonia of calves. Vet.Pathol. 1991, 28, 286-292.

Bryson DG, McFerran JB, Ball HJ, Neill SD: Observations on outbreaks of respiratory disease in housed calves.(1) Epidemiological, clinical and microbiological findings. Vet.Rec. 1978, 103, 485-489.

Bryson DG, McNulty MS, Logan EF, Cush PF: Respiratory syncytial virus pneumonia in young calves: clinical and pathologic findings. Am.J Vet.Res. 1983, 44, 1648-1655.

Buchholz UJ, Finke S, Conzelmann KK: Generation of bovine respiratory syncytial virus (BRSV) from cDNA: BRSV NS2 is not essential for virus replication in tissue culture, and the human RSV leader region acts as a functional BRSV genome promoter. J.Virol. 1999, 73, 251-259.

Butler JE: Bovine immunoglobulins: an augumented review. Vet. Immunol. Immunopathol. 1983, 4, 43-152.

Cash P, Wunner WH, Pringle CR: A comparison of the polypeptides of human and bovine respiratory syncytial viruses and murine pneumonia virus. 
Virology 1977, 82, 369-379.

Castleman WL, Chandler SK, Slauson DO: Experimental bovine respiratory syncytial virus infection in conventional calves: ultrastructural respiratory lesions. Am.J.Vet.Res. 1985a, 46, 554-560.

Castleman WL, Lay JC, Dubovi EJ, Slauson DO: Experimental bovine respiratory syncytial virus infection in conventional calves: light microscopic lesions, microbiology, and studies on lavaged lung cells. Am.J.Vet.Res. 1985b, 46, 547-553.

Chanock R, Roizman B, Myers R: Recovery from infants with respiratory illness of a virus related to chimpanzee coryza agent (CCA). I. Isolation, properties and characterization. Am.J.Hyg. 1957, 66, 281-290.

Chanock RM, Kim HW, Vargosko AJ, Deleva A, Johnson KM, Cumming C, Parrot RH: Respiratory syncytial virus. I. Virus recovery and other observations during 1960 outbreak of bronchilitis, pneumonia, and minor respiratory disease in children. JAMA 1961, 176, 653-653.

Collins JK, Jensen R, Smith GH, Flack DE, Kerschen $R$, Bennett BW, Jones RL, Alexander AF: Association of bovine respiratory syncytial virus with atypical interstitial pneumonia in feedlot cattle. Am.J.Vet.Res. 1988, 49, 1045-1049.

Collins PL, McIntosh K, Chanock RM: Field BN, Knipe DM, editors. Fields Virology. 3 ed. New York: Raven Press 1996, 44, Pneumnovirinae. p. 1313-51.

Collins PL, Hill MG, Johnson PR: The two open reading frames of the $22 \mathrm{~K}$ mRNA of human respiratory syncytial virus: sequence comparison of antigenic subgroups $\mathrm{A}$ and $\mathrm{B}$ and expression in vitro. J.Gen.Virol. 1990, 71, 3015-3020.

Collins PL, Mottet G: Membrane orientation and oligomerization of the small hydrophobic protein of human respiratory syncytial virus. J.Gen.Virol. 1993, 74, 1445-1450.

Collins $P L$, Wertz $G W$ : cDNA cloning and transcriptional mapping of nine polyadenylated RNAs encoded by the genome of human respiratory syncytial virus. Proc.Natl.Acad.Sci.U.S.A. 1983, 80, 3208-3212.

Elazhary MASY, Silim A, Dea S: Prevalence of antibodies to bovine respiratory syncytial virus, bovine viral diarrhea virus, bovine herpesvirus-1, and bovine parainfluenza-3 virus in sheep and goats in Quebec. Am.J.Vet.Res. 1984, 45, 1660 1662.

Ellis JA, Philibert $H$, West $K$, Clark E, Martin $K$, Haines $D$ : Fatal pneumonia in adult dairy cattle associated with active infection with bovine respiratory syncytial virus. Can.Vet.J. 1996, 37, 103-105.

Ellis JA, Russell H, Cavender J, Haven TR: Bovine respiratory syncytial virus-specific immune responses in cattle following immunization with modified-live and inactivated vaccines. Analysis of the specificity and activity of serum antibodies. Vet.Immunol.Immunopathol. 1992, 34, 3545.

Elvander $M$ : Severe respiratory disease in dairy cows caused by infection with bovine respiratory syncytial virus. Vet.Rec. 1996, 138, 101-105.

Evans JE, Cane PA, Pringle CR: Expression and characterisation of the NS1 and NS2 proteins of respiratory syncytial virus. Virus Res. 1996, 43, 155-161.

Fisher JE, Johnson JE, Kuli-Zade RK, Johnson TR, Aung $S$, Parker RA, Graham BS: Overexpression of interleukin-4 delays virus clearence in mice infected with respiratory syncytial virus. J.Virol. 1997, 71, 8672-8677.

Fulginiti VA, Eller JJ, Sieber OF, Joyner JW, Minamitani $M$, Meiklejohn $G$ : A field trial of two inactivated respiratory virus vaccines; an aqueous trivalent parainfluenza virus vaccine and an alunprecipitated respiratory syncytial virus vaccine. Am.J.Epidemiol. 1969, 89, 435-448.

Fulton RW, Confer AW, Burge LJ, Perino LJ, Doffay $J M$, Payton ME, Mock RE: Antibody responses by cattle after vaccination with commercial viral vaccines containing bovine herpesvirus-1, bovine viral diarrhea virus, parainfluenza-3 virus, and bovine respiratory syncytial virus immunogens and subsequent revaccination at day 140 . Vaccine 1995, 13, 725-733.

Furze J, Wertz $G$, Lerch $R$, Taylor G: Antigenic heterogeneity of the attachment protein of bovine respiratory syncytial virus. J.Gen. Virol. 1994, 75, 363-370.

Furze JM, Roberts SR, Wertz GW, Taylor G: Antigenically distinct $\mathrm{G}$ glycoproteins of BRSV strains share a high degree of genetic homogeneity. Virology 1997, 231, 48-58.

Garcia J, Garcia Barreno B, Vivo A, Melero JA: Cytoplasmic inclusions of respiratory syncytial virus-infected cells: formation of inclusion bodies in transfected cells that coexpress the nucleoprotein, the phosphoprotein, and the $22 \mathrm{~K}$ protein. Virology 1993, 195, 243-247.

Gershwin LJ, Woolums AR, Gunther RA, Anderson $M L$, Larochelle DRBGA, Friebertshauser $K E$, 
Singer RS: A bovine model of vaccine enhanced respiratory syncytial virus patophysiology. Vaccine 1998, 16, 1225-1236.

Gimenez HB, Chisholm S, Dornan J, Cash P: Neutralizing and enhancing activities of human respiratory syncytial virus-specific antibodies. Clin.Diagn.Lab.Immunol. 1996, 3, 280-286.

Graham BS: Immunological determinants of disease caused by respiratory syncytial virus. Trends in Microbiology 1996, 4, 290-294.

Haines DM, Clark EG, Chelack BJ: The detection of bovine respiratory syncytial virus in formalin fixed bovine lung with commercially available monoclonal antibodies and avidin biotin complex immunohistochemistry. Can.J.Vet.Res. 1989, 53, 366-368.

Hardy $R W$,Wertz $G W$ : The product of the respiratory syncytial virus M2 gene ORF1 enhances readthrough of intergenic junctions during viral transcription. J.Virol. 1998, 72, 520-526.

Himes SR, Gershwin LJ: Bovine respiratory syncytial virus fusion protein gene: sequence analysis of cDNA and expression using a baculovirus vector. J.Gen.Virol. 1992, 73, 1563-1567.

Howard CJ, Stott EJ, Thomas LH, Gourlay RN, Taylor $G$ : Protection against respiratory disease in calves induced by vaccines containing respiratory syncytial virus, parainfluenza type 3 virus, Mycoplasma bovis and M. dispar. Vet.Rec. 1987, 121, 372-376.

Huang YT,Wertz $G W$ : The genome of respiratory syncytial virus is a negative-stranded RNA that codes for at least seven mRNA species. J.Virol. 1982, 43, 150-157.

Inaba Y, Tanaka Y, Sato K, Ito H, Omori T, Matumoto $M$ : Nomi virus, a virus isolated from an appearently new epizootic respiratory disease of cattle. Japan.J.Microbiol. 1970, 14, 246-248.

Inaba Y, Tanaka Y, Sato K, Omori T, Matumoto M: Bovine respiratory syncytial virus. Studies on an outbreak in Japan. 1968-1969. Japan.J.Microbiol. 1972, 16, 373-383.

Ito Y, Tanaka Y, Inaba Y, Omori T: Structure of bovine respiratory syncytial virus. Arch. Ges. Virusforsch. 1973, 40, 198-204.

Jackson M, Scott R: Different patterns of cytokine induction in cultures of respiratory syncytial (RS) virus-specific human $\mathrm{TH}$ cell lines following stimulation with RS virus and RS virus proteins. J.Med.Virol. 1996, 49, 161-169.

Jacobs JW, Edington N: Experimental infection of calves with respiratory syncytial virus. Res.
Vet.Sci. 1975, 18, 299-306.

Jacops JW, Edington N: Isolation of respiratory syncytial virus from cattle in Britian. Vet.Rec. 1971, 88, 694-694.

Johnson JL, Pommer JL, Hudson DB, Doster AR: Pulmonary emphysema in weaned calves: Laboratory diagnosis. Bovine Proceedings. 1982, 14, 122-126.

Kim HW, Canchola JG, Brandt CD, Pyles G, Chanock RM, Jensen $K$, Parrot $R H$ : Respiratory syncytial virus disease in infants despite prior administration of antigenic inactivated vaccine. Am.J.Epidemiol. 1969, 89, 422-434.

Kimman TG, Sol J, Westenbrink F, Straver PJ: A severe outbreak of respiratory tract disease associated with bovine respiratory syncytial virus probably enhanced by vaccination with modified live vaccine. Vet.Q. 1989b, 11, 250-253.

Kimman TG, Straver PJ, Zimmer GM: Pathogenesis of naturally acquired bovine respiratory syncytial virus infection in calves: morphologic and serologic findings. Am.J.Vet.Res. 1989, 50, 684-693.

Kimman TG,Westenbrink F: Immunity to human and bovine respiratory syncytial virus. Arch.Virol. 1990, 112, 1-25.

Kimman TG, Westenbrink F, Schreuder BE, Straver $P J$ : Local and systemic antibody response to bovine respiratory syncytial virus infection and reinfection in calves with and without maternal antibodies. J. Clin. Microbiol. 1987, 25, 10971106.

Kimman TG, Westenbrink F, Straver PJ: Priming for local and systemic antibody memory responses to bovine respiratory syncytial virus: effect of amount of virus, virus replication, route of administration and maternal antibodies. Vet.Immunol.Immunopathol. 1989a, 22, 145-160.

Kimman TG, Westenbrink F, Straver PJ, Van Zaane D, Schreuder BE: Isotype-specific ELISAs for the detection of antibodies to bovine respiratory syncytial virus. Res. Vet.Sci. 1987, 43, 180-187.

Kimman TG, Zimmer GM, Westenbrink F, Mars J, Leeuwen E, van Leeuwen E: Epidemiological study of bovine respiratory syncytial virus infections in calves: influence of maternal antibodies on the outcome of disease. Vet.Rec. 1988, 123, 104-109.

Kimpen JL, Rich GA, Mohar CK, Ogra PL: Mucosal $\mathrm{T}$ cell distribution during infection with respiratory syncytial virus. J.Med.Virol. 1992, 36, 172179.

Kubota M, Fukuyama S, Takamura K, Izumida A, 
Kodama $K$ : Field trials on a live bovine respiratory syncytial virus vaccine in calves. J. Vet. Med.Sci. 1992, 54, 957-962.

Kuo L, Fearns R, Collins PL: The structurally diverse intergenic regions of respiratory syncytial virus do not modulate sequential transcription by a dicistronic minigenome. J.Virol. 1996, 70, 61436150 .

Langedijk JP, Meloen RH, Taylor G, Furze JM, Van Oirschot JT: Antigenic structure of the central conserved region of protein $\mathrm{G}$ of bovine respiratory syncytial virus. J.Virol. 1997, 71, 40554061.

Langedijk JP, Middel WG, Schaaper WM, Meloen RH, Kramps JA, Brandenburg AH, Van Oirschot $J T$ : Type-specific serologic diagnosis of respiratory syncytial virus infection, based on a synthetic peptide of the attachment protein. J.Immunol.Methods 1996, 193, 157-166.

Larsen LE, Tjørnehøj K, Viuff B, Jensen NF, Uttenthal Aa: Diagnosis of enzootic pneumonia in Danish cattle: application of the reverse transcription-polymerase chain reaction (RT-PCR) assay for detection of bovine respiratory syncytial virus in naturally and experimentally infected calves. J.Vet.Diagn.Invest. 1999, 11, 416-422.

Larsen LE, Uttenthal Aa, Arctander P, Tjørnehøj K, Viuff B, Røntved C, Rønsholt L, Alexandersen $S$, Blixenkrone-Møller M: Serological and genetic characterisation of bovine respiratory syncytial virus (BRSV) indicates that Danish isolates belong to the intermediate subgroup: no evidence of a selective effect on the variability of $G$ protein nucleotide sequence by prior cell culture adaption and passages. Vet.Microbiol. 1998, 62, 265279.

Lekeux P: Bovine respiratory disease complex: An European perspective. Bov.Pract. 1995, 29, 7175.

Lerch RA, Anderson K, Amann VL, Wertz GW: Nucleotide sequence analysis of the bovine respiratory syncytial virus fusion protein mRNA and expression from a recombinant vaccinia virus. Virology 1991, 181, 118-131.

Lerch $R A$, Anderson $K$, Wertz $G W$ : Nucleotide sequence analysis and expression from recombinant vectors demonstrate that the attachment protein $\mathrm{G}$ of bovine respiratory syncytial virus is distinct from that of human respiratory syncytial virus. J.Virol. 1990, 64, 5559-5569.

Lerch RA, Stott EJ, Wertz GW: Characterization of bovine respiratory syncytial virus proteins and
mRNAs and generation of cDNA clones to the viral mRNAs. J.Virol. 1989, 63, 833-840.

Levine S, Klaiber Franco R, Paradiso PR: Demonstration that glycoprotein $\mathrm{G}$ is the attachment protein of respiratory syncytial virus. J.Gen.Virol. 1987, 68, 2521-2524.

Lokensgard BE, Goyal SM, Krueger DA: Comparison of three immunoassays for the rapid detection of bovine respiratory syncytial virus. Microbiologica 1992, 15, 259-264.

Mallipeddi SK, Samal SK: Sequence comparison between the phosphoprotein mRNAs of human and bovine respiratory syncytial viruses identifies a divergent domain in the predicted protein. J.Gen.Virol. 1992, 73, 2441-2444.

Mallipeddi SK, Samal SK: Analysis of the ovine respiratory syncytial virus (RSV) G glycoprotein gene defines a subgroup of ungulate RSV. J.Gen.Virol. 1993, 74, 2787-2791.

Mallipeddi SK, Samal SK: Sequence variability of the glycoprotein gene of bovine respiratory syncytial virus. J.Gen.Virol. 1993, 74, 2001-2004.

Mallipeddi SK, Samal SK, Mohanty SB: Analysis of polypeptides synthesized in bovine respiratory syncytial virus-infected cells. Arch.Virol. 1990, 115, 23-36.

Mars MH, Bruschke CJM, Oirschot JT: Airborne transmission of BHV1, BRSV and BVDV among cattle is possible under experimental conditions. Vet. Microbiol. 1999, 66, 197-207.

Martin HT: Indirect haemagglutination test for the detection and assay of antibodies to bovine respiratory syncytial virus. Vet.Rec. 1983, 113, 290293.

Matheise JP, Walravens K, Collard A, Coppe P, Letesson $J J$ : Antigenic analysis of the $\mathrm{F}$ protein of the bovine respiratory syncytial virus: identification of two distinct antigenic sites involved in fusion inhibition. Arch.Virol. 1995, 140, 993-1005.

Matumoto M, Inaba Y, Kuroci H, Sato K, Omori T, Goto $Y$, Hirose $O$ : Bovine respiratory syncytial virus: host range in laboratory animals and cell cultures. Arch. Ges. Virusforsch. 1974, 4, 280290.

Midulla F, Villani A, Panuska JR, Dab I, Kolls JK, Merolla $R$, Ronchetti $R$ : Respiratory syncytial virus lung infection in infants: immunoregulatory role of infected alveolar macrophages. J. Infect. Dis. 1993, 168, 1515-1519.

Mohanty SB, Davidson JP, Sharabrin OI, Forst SM: Effect of vaccinal serum antibodies on bovine respiratory syncytial viral infection in calves. 
Am.J.Vet.Res. 1981, 42, 881-883.

Mohanty $S B$, Ingling $A L$, Lillie $M G$ : Experimentally induced respiratory syncytial viral infection in calves. Am.J.Vet.Res. 1975, 36, 417-419.

Morris JA, Blount RE, Savage RE: Recovery of cytopathogenic agent from chimpanzees with coryza. Proc.Soc.Exp.Biol.Med. 1956, 92, 544-549.

Murphy BR, Prince GA, Walsh EE, Kim HW, Parrot RH, Hemming VG, Rodriguez WJ, Chanock RM: Dissociation between serum neutralizing and glycoprotein antibody responses of infants and children who received inactivated respiratory syncytial virus vaccine. J. Clin. Microbiol. 1986, 24, 197-202.

Murphy BR, Walsh EE: Formalin-inactivated respiratory syncytial virus vaccine induces antibodies to the fusion glycoprotein that are deficient in fusion-inhibiting activity. J.Clin.Microbiol. 1988, 26, 1595-1597.

Murphy FA, Famfuet CM, Bishop DHL, Ghabrial SA, Jarvis AW, Martelli GP, Mayo MA, Summers MD: Virus Taxonomy, Sixth report on taxonomy of the international comittee on taxonomy of viruses. Arch.Virol. 1995, Suppl. 10.

Olmsted RA,Collins PL: The 1A protein of respiratory syncytial virus is an integral membrane protein present as multiple, structurally distinct species. J.Virol. 1989, 63, 2019-2029.

Openshaw PJ: Immunopathological mechanisms in respiratory syncytial virus disease. Springers Seminar on Immunopathology. 1995, 17, 187201.

Otto P, Elschner M, Reinhold P, Kohler H, Streckert HJ, Philippou S, Werchau H, Morgenroth K: A model for respiratory syncytial virus (RSV) infection based on experimental aerosol exposure with bovine RSV in calves. Comp. Immunol. Microbiol. Infect. Dis. 1996, 19, 85-97.

Paccaud MF and Jacquire C: A respiratory virus of bovine origin. Arch.Ges.Virusforsch. 1970, 303, 27-42.

Panuska JR, Cirino NM, Midulla F, Despot JE, McFadden ER, Jr., Huang YT: Productive infection of isolated human alveolar macrophages by respiratory syncytial virus. J. Clin. Invest. 1990, 86, 113-119.

Pastey MK,Samal SK: Nucleotide sequence analysis of the non-structural NS1 (1C) and NS2 (1B) protein genes of bovine respiratory syncytial virus. J.Gen.Virol. 1995, 76, 193-197.

Pastey MK,Samal SK: Analysis of bovine respiratory syncytial virus envelope glycoproteins in cell fu- sion. J.Gen.Virol. 1997, 78, 1885-1889.

Pirie HM, Petrie L, Allan EM, Pringle CR: Acute fatal pneumonia in calves due to respiratory syncytial virus. Vet.Rec. 1981, 109, 87-97.

Poch O, Blumberg BM, Bougueleret L, Tordo N: Sequence comparison of five polymerases (L proteins) of unsegmented negative-strand RNA viruses: theoretical assignment of functional domains. J.Gen. Virol. 1990, 71, 1153-1162.

Potgieter ND, Aldridge PL: Use of indirect fluoroscent antibody test in the detection of bovine respiratory syncytial virus antibodies in bovine serum. Am.J.Vet.Res. 1977, 38, 1341-1343.

Prozzi D, Walravens K, Langedijk JPM, Daus F, Kramps $J A$ : Antigenic and molecular analysis of the variability of bovine respiratory syncytial virus G glycoprotein. J.Gen.Virol. 1997, 78, 359366.

Richardson C, Hull D, Greer P, Hasel K, Berkovich A, Englund $G$, Berllini $W$, Rima $B$, Lazzarini R: The nucleotide sequence of the mRNA encoding the fusion protein of measles virus (Edmonton strain): A comparison of fusion proteins from several different paramyxoviruses. Virology 1986, 155, 508-523.

Richman AV, Pedreira FA, and Tauraso NM: Attempts to demonstrate heamagglutination and hemadsorption by respiratory syncytial virus. Apppl. Microbiol. 1971, 21, 1099-100.

Roberts SR, Compans RW, Wertz GW: Respiratory syncytial virus matures at the apical surfaces of polarized epithelial cells. J.Virol. 1995, 69, 2667 2673.

Samal SK, Pastey MK, McPhillips T, Carmel DK, Mohanty SB: Reliable confirmation of antibodies to bovine respiratory syncytial virus (BRSV) by enzyme-linked immunosorbent assay using BRSV nucleocapsid protein expressed in insect cells. J.Clin.Microbiol. 1993, 31, 3147-3152.

Samal SK, Zamora M: Nucleotide sequence analysis of a matrix and small hydrophobic protein dicistronic mRNA of bovine respiratory syncytial virus demonstrates extensive sequence divergence of the small hydrophobic protein from that of human respiratory syncytial virus. J. Gen. Virol. 1991, 72, 1715-1720.

Samal SK, Zamora M, McPhillips TH, Mohanty SB: Molecular cloning and sequence analysis of bovine respiratory syncytial virus mRNA encoding the major nucleocapsid protein. Virology 1991, 180, 453-456.

Schrijver RS, Daus F, Kramps JA, Langedijk JPM, 
Buijs R, Middel WGJ, Taylor G, Furze J, Huyben $M W C$, van Oirschot JT: Subgrouping of bovine respiratory syncytial virus strains detected in lung tissue. Vet.Microbiol. 1996, 53, 253-260.

Schrijver RS, Kramps JA, Middel WG, Langedijk JP, Van Oirschot JT: Bovine respiratory syncytial virus replicates minimally in bovine alveolar macrophages. Arch.Virol. 1995, 140, 1905-1917.

Schrijver RS, Langedijk JP, Keil GM, Middel WG, Maris-Veldhuis M, Van Oirschot JT, Rijsewijk FAM: Immunization of cattle with a BHV1 vector vaccine or a DNA vaccine both coding for the G protein of BRSV. Vaccine 1997, 15, 19081916.

Schrijver RS, LangedijkJP, Van der Poel WH, Middel WG, Kramps JA, Van Oirschot JT: Antibody responses against the $G$ and $F$ proteins of bovine respiratory syncytial virus after experimental and natural infections. Clin. Diagn. Lab. Immunol. 1996, 3, 500-506.

Shadomy SV, Baker JC, Mufson MA, Velicer LL: Phosphoprotein profile analysis of ruminant respiratory syncytial virus isolates. Am.J.Vet.Res. 1997, 58, 478-481.

Sharma $A K$, Woldehiwet $Z$ : Cell-mediated immune responses of lambs to experimental infection with bovine respiratory syncytial virus. Vet.Immunol.Immunopathol. 1996, 50, 79-91.

Sharma AK, Woldehiwet Z: Replication of bovine respiratory syncytial virus in ovine peripheral blood lymphocytes and monocytes in vitro. Vet. Microbiol. 1996, 48, 125-134.

Sharma R, Woldehiwet Z, Spiller DG, Warenius HM: Lymphocyte subpopulations in peripheral blood of lambs experimentally infected with bovine respiratory syncytial virus. Vet.Immunol. Immunopathol. 1990, 24, 383-391.

Smith MH, Frey ML, Dierks RE: Isolation, characterization, and pathogenicity studies of a bovine respiratory syncytial virus. Arch.Virol. 1975, 47, 237-247.

Smith MH, Lehmkuhl HD, Phillips SM: Isolation and characterization of a respiratory syncytial virus from goats. Proc. Am. Ass. Vet. Lab. Diagn. 1979, 22, 259-267.

Stine LC, Hoppe DK, Kelling CL: Sequence conservation in the attachment glycoprotein and antigenic diversity among bovine respiratory syncytial virus isolates. Vet.Microbiol. 1997, 54, 201-221.

Stott EJ, Thomas LH, Collins AP, Crouch S, Jebbett J, Smith GS, Luther PD, Caswell R: A survey of vi- rus infections of the respiratory tract of cattle and their association with disease. J.Hyg. 1980, 85, 257-270.

Stott EJ, Thomas LH, Taylor G, Collins AP, Jebbett J, Crouch S: A comparison of three vaccines against respiratory syncytial virus in calves. J.Hyg. 1984, 93, 251-261.

Taylor G, Thomas LH, Stott EJ: Effect of vaccination on cell populations in lung washes from calves after infection with respiratory syncytial virus. Res.Vet.Sci. 1989, 47, 231-235.

Taylor G, Thomas LH, Wyld SG, Furze J, Sopp P, Howard $C J$ : Role of T-lymphocyte subsets in recovery from respiratory syncytial virus infection in calves. J.Virol. 1995, 69, 6658-6664.

Thomas LH, Cook RS, Howard CJ, Gaddum RM, Taylor G: Influence of selective T-lymphocyte depletion on the lung pathology of gnotobiotic calves and the distribution of different T-lymphocyte subsets following challenge with bovine respiratory syncytial virus. Res.Vet.Sci. 1996, 61, 38-44.

Thomas LH, Stott EJ: Diagnosis of respiratory syncytial virus infection in the bovine respiratory tract by immunofluorescence. Vet. Rec. 1981, 108, 432-435.

Thomas LH, Stott EJ, Collins AP, Crouch S, Jebbett J: Infection of gnotobiotic calves with a bovine and human isolate of respiratory syncytial virus. Modification of the response by dexamethasone. Arch.Virol. 1984, 79, 67-77.

Thomas LH, Stott EJ, Collins AP, Jebbett J: Experimental pneumonia in gnotobiotic calves produced by respiratory syncytial virus. Br.J.Exp.Pathol. 1984, 65, 19-28.

Thomas LH, Stott EJ, Jones PW, Jebbett NJ, Collins $A P$ : The possible role of respiratory syncytial virus and Pasteurella spp in calf respiratory disease. Vet.Rec. 1980, 107, 304-307.

Toth T, Hesse RA: Replication of five bovine respiratory viruses in cultured bovine alveolar macrophages. Arch.Virol. 1983, 75, 219-224.

Trigo FJ, Breeze RG, Evermann JF, Gallina AM: Pathogenesis of experimental bovine respiratory syncytial virus infection in sheep. Am.J.Vet.Res. 1984, 45, 1663-1670.

Trudel M, Nadon F, Simard C, Belanger F, Alain R, Seguin C, Lussier G: Comparison of caprine, human and bovine strains of respiratory syncytial virus. Arch.Virol. 1989, 107, 141-149.

Uttenthal A, Jensen NP, Blom JY: Viral aetiology of enzootic pneumonia in Danish dairy herds: diag- 
nostic tools and epidemiology. Vet. Rec. 1996, 139, 114-117.

Van der Poel WH, Kramps JA, Middel WG, Van Oirschot JT, Brand A: Dynamics of bovine respiratory syncytial virus infections: a longitudinal epidemiological study in dairy herds. Arch.Virol. 1993, 133, 309-321.

Van der Poel WH, Langedijk JP, Kramps JA, Middel WG, Brand A, Van Oirschot JT: Bovine respiratory syncytial virus antibodies in non-bovine species. Arch.Virol. 1995, 140, 1549-1555.

Van der Poel WH, Langedijk JPM, Kramps JA, Middle WGJ, Brand A, Van Oirschot JT: Serological indication for persistence of bovine respiratory syncytial virus in cattle and attemps to detect the virus. Arch.Virol. 1997, 142, 1681-1696.

Van der Poel WH, Schrijver RS, Middel WG, Kramps JA, Brand A, Van Oirschot JT: Experimental reproduction of respiratory disease in calves with non-cell-culture-passaged bovine respiratory syncytial virus. Vet.Q. 1996, 18, 81-86.

Van der Poel WHM, Mourits MCM, Nielen M, Frankena K, Vanoirschot JT, Schukken YH: Bovine respiratory syncytial virus reinfections and decreased milk yield in dairy cattle. Vet. Q. 1995, 17, 77-81.

Vaux Peretz F, Chapsal JM, Meignier B: Comparison of the ability of formalin-inactivated respiratory syncytial virus, immunopurified $\mathrm{F}, \mathrm{G}$ and $\mathrm{N}$ proteins and cell lysate to enhance pulmonary changes in Balb/c mice. Vaccine 1992, 10, 113118.

Verhoeff J, van Nieuwstadt APKMI: Prevention of bovine respiratory syncytial virus infection and clinical disease by vaccination. Vet. Rec. 1984, $115,488-492$.

Verhoeff J, Van Nieuwstadt APKMI: BRS virus, PI3 virus and BHV1 infections of young stock on self- contained dairy farms: epidemiological and clinical findings. Vet.Rec. 1984, 114, 288-293.

Viuff B, Uttenthal A, Tegtmeier C, Alexandersen S: Sites of replication of bovine respiratory syncytial virus in naturally infected calves as determined by in situ hybridization. Vet.Pathol. 1996, 33, 383-390.

Westenbrink F, Brinkhof JMA, Straver PJ, Quak J, Leeuw PWd, De Leeuw PW: Comparison of a newly developed enzyme-linked immunosorbent assay with complement fixation and neutralisation tests for serology of bovine respiratory syncytial virus infections. Res.Vet.Sci. 1985, 38, 334-340.
Westenbrink F, Kimman TG: Immunoglobulin Mspecific enzyme-linked immunosorbent assay for serodiagnosis of bovine respiratory syncytial virus infections. Am.J.Vet.Res. 1987, 48, 11321137.

Westenbrink F, Kimman TG, Brinkhof JM: Analysis of the antibody response to bovine respiratory syncytial virus proteins in calves. J.Gen.Virol. 1989, 70, 591-601.

$Y u Q, \operatorname{Hardy} R W$, Wertz $G W$ : Functional cDNA clones of the human respiratory syncytial (RS) virus N, $\mathrm{P}$, and $\mathrm{L}$ proteins support replication of RS virus genomic RNA analogs and define minimal transacting requirements for RNA replication. J.Virol. 1995, 69, 2412-2419.

Zamora M, Samal SK: Gene junction sequences of bovine respiratory syncytial virus. Virus Res. 1992, 24, 115-121.

Zamora M, Samal SK: Sequence analysis of M2 mRNA of bovine respiratory syncytial virus obtained from an F-M2 dicistronic mRNA suggests structural homology with that of human respiratory syncytial virus. J.Gen.Virol. 1992, 73, 737 741.

\section{Sammendrag}

Bovint respiratorisk syncytial virus (BRSV): Review.

Infektion med bovint respiratorisk syncytial virus (BRSV) er den hyppigste årsag til lungebetændelse hos specielt yngre kalve. Anvendelse af nyere molekylærbiologiske metoder har de senere år resulteret $\mathrm{i}$ en eksplosiv vækst af publicerede artikler om handlende dette virus og den infektion, det er årsag til.

BRSV er et enkelt-strenget RNA virus, der tilhører genus Pneumovirus. Infektionen rammer primært yngre kalve, hvor det giver anledning til alvorlig lungebetændelse med kraftige kliniske symptomer og udbredte lungeforandringer. Erhvervede eller passivt overførte antistoffer synes ikke at beskytte fuldt mod infektion, idet selv kalve med maternel immunitet inficeres ligesom ældre dyr hyppigt gennemgår reinfektion, der dog ikke giver anledning til alvorlig sygdom. Smittevejene er delvis ukendte, men tæt kontakt er formodentlig nødvendig. Immunopatologiske mekanismer synes at bidrage til sygdomsudviklingen, hvilket menes at være medvirkende årsag til, at det er problematisk at vaccinere mod infektionen.

Baseret på cirka 140 referencer præsenteres et opda- 
teret overblik omhandlende BRSV, herunder de væsentlige aspekter af virusstruktur, molekylær bio- logi, patogenese, patologi, kliniske tegn, epidemiologi, diagnose og immunologi.

(Received February 10, 1999; accepted December 28, 1999).

Reprints may be obtained from: L. E. Larsen, Danish Veterinary Laboratory; Bülowsvej 27, DK-1790 Copenhagen V, Denmark. E-mail: lel@svs.dk, tel: +45 353002 74, fax: 35300340. 